\title{
JEZUITSKÁ TEÓRIA DRÁMY \\ A JEJ ODRAZ V BAROKOVOM ŠKOLSKOM DIVADLE SPOLOČNOSTI JEŽIŠOVEJ NA ÚZEMÍ DNEŠNÉHO SLOVENSKA
}

\author{
LUKÁŠ KOPAS \\ Centrum výskumu divadla Divadelného ústavu, Bratislava
}

\begin{abstract}
Abstrakt: Ambíciou štúdie je vymedził mieru uplatňovania teoretických východísk najvýznamnejších jezuitských dramatických poetík v rádovej dramaticko-divadelnej praxi na území dnešného Slovenska v období baroka. Predmetom štúdie je konfrontácia teoretických rámcov jednej zo štyroch doposial' známych fundamentálnych učebných pomôcok skalického vzdelávacieho inštitútu Collegium repetentium humaniorum - čistopisu rukopisného kompendia latinského jazyka a reálií s názvom Commentarii in Litteras Humaniores (Poznámky k humanitným vedám), ktorého kapitola De Drammatibus (O drámach) sumarizuje jezuitskú teóriu drámy etablovaných európskych autorov 17. storočia - so sujetom jezuitskej školskej hry Jozefa Bartakoviča s názvom Moyses (Mojžiš), ktorá bola 15. júla 1749 predvedená v Trnave.

Kl'účové slová: barok, školská hra, jezuiti, rádové gymnaziálne školstvo, kompendium, Skalica, Commentarii in Litteras Humaniores, Trnavská univerzita, Jozef Bartakovič, Moyses
\end{abstract}

Jezuitská dramaticko-divadelná produkcia dosiahla na území dnešného Slovenska svoj vývojový zenit v rokoch $1650-1780^{1}$, čomu predchádzala fáza renesančno-humanistického vývinu rádovej školskej hry. ${ }^{2} \mathrm{~V}$ porovnaní s predchádzajúcou kultúrno-historickou epochou, v období baroka u nás jezuitská školská hra predstavovala jeden z najdominantnejších divadelných prejavov náboženskej línie súdobej dramaticko-divadelnej tvorby, ktorá kvantitou umeleckej produkcie prevyšovala divadelné prejavy svetskej línie barokového divadla. ${ }^{3}$

Z hl’adiska druhovej diferenciácie mala jezuitská školská dráma v tomto období charakter náboženských, polosvetských a svetských hier. V náboženských hrách spracovávali rádoví autori starozákonnú, novozákonnú, vieroučnú a legendovú tematiku, pričom v polosvetských a svetských hrách stála v centre ich pozornosti historická, resp. súveká politická tematika. ${ }^{4}$

V súvislosti s typologickou diferenciáciou jezuitskej školskej hry druhej polovice 17. a 18. storočia musíme nevyhnutne uvažovat’ o jej troch základných typoch ako ich definoval slovenský muzikológ a slavista Ladislav Kačic. ${ }^{5} \mathrm{~K}$ elementárnemu typu

\footnotetext{
${ }^{1}$ Epochu slovenskej barokovej literatúry vrátane drámy diferencuje Jozef Minárik na etapu začiatkov (1650 - 1680), etapu rozkvetu (1680 - 1750) a etapu ústupu (1750 - 1780). Pozri MINÁRIK, J. Baroková literatúra svetová, česká, slovenská. Bratislava : Slovenské pedagogické nakladatel’stvo, 1984, s. 50.

${ }^{2}$ Pozri PAŠTEKA, J. K trnavskej tradícii jezuitského barokového divadla : niekol'ko poznámok na okraj vel'kej témy. In Slovenské divadlo, 1993, roč. 41, č. 3, s. 249.

${ }^{3}$ Pozri MINÁRIK, J. Baroková literatúra svetová, česká, slovenská, s. $54-313$.

${ }^{4}$ Pozri tamže, s. 64.

${ }^{5}$ Pozri KAČIC, L. Jezuitská školská hra a hudba na Slovensku v 17. - 18. storočí. In Jezuitské školstvo včera a dnes : zborník z medzinárodnej vedeckej konferencie 12. októbra 2006 v Trnave. (Ed. L. Csontos). Trnava : Dobrá kniha, 2006, s. $177-179$.
} 
školských produkcií patrili tzv. declamationes (deklamácie), v rámci ktorých menšia skupina žiakov predvádzala (bud' verejne alebo interne) svoje monológy, dialógy, prípadne kratšie dramatické scénky. Hoci sa v nich hudba takmer nevyužívala, niekedy sa muzikálni žiaci mohli prezentovat’ aj spevom. Zložitejší typ školskej produkcie predstavovala tzv. drama minus (malá dráma). Išlo o zhruba hodinovú školskú hru, ktorá sa nečlenila na dejstvá a mnohokrát mala zhudobnený prológ a epilóg, vrátane intermédia uprostred dramatického deja. Popri monológoch a dialógoch obsahovala aj spievané slovo či nenáročný tanec. Najvyšším typom školskej produkcie bola tzv. drama majus (vel'ká dráma). Na tomto type inscenácie, ktorá sa nezaobišla bez bohatej javiskovej výpravy, participovali žiaci celej školy. Tzv. vel'ké drámy boli uvádzané pri príležitosti konca školského roka, významných sviatkov a návštev, pričom ich trvanie mohlo dosiahnut' aj niekol'ko hodín. Pozostávali prinajmenšom z troch (avšak často až z piatich) dejstiev, spravidla obsahovali zhudobnený prológ, dve (prípadne až štyri) medzidejstvové intermédiá a epilóg. Svoje miesto v nich mal aj náročnejší tanec - balet.

Ako to vyplývalo zo študijného poriadku Spoločnosti Ježišovej (1599), resp. zo samotného poslania jezuitskej školskej drámy (akcentovanie mravoučných, vieroučných, nábožensko-propagačných a predovšetkým pedagogicko-didaktických cielov $)^{6}$, rozhodujúcu úlohu $\mathrm{v}$ rádovej dramaticko-divadelnej tvorbe zohrávalo jeho gymnaziálne školstvo. To v období baroka predstavovalo humanistický typ výchovno-vzdelávacej inštitúcie, kde sa kládol dôraz najmä na výučbu latinského jazyka a reálií. ${ }^{7}$

Uchádzačov o štúdium na jezuitskom gymnáziu prijímal praefectus scholarum inferiorum (prefekt nižších škôl), prípadne len praefectus scholarum (školský prefekt), čo záviselo od toho, či súčastou toho-ktorého kolégia bola aj univerzita alebo len gymnázium. Smerodajný význam mali v tomto kontexte prijímacie skúšky. $\mathrm{V}$ rámci nich museli chlapci (bez ohl'adu na pôvod) preukázat’ mieru doterajšieho vzdelania, resp. vedomostí, a to napríklad prostredníctvom krátkeho písomného cvičenia, prekladu do latinčiny a interpretácie textu. Ak uspeli, prefekt, ktorý vo všeobecnosti zodpovedal za kvalitu a chod výučby, sa zaujímal aj o ich správanie ${ }^{8}$, o ktorom sa informoval u rodičov či pestúnov. Po zápise do zoznamu študentov boli chlapci podla výsledku prijímacej skúšky a po dohode s kompetentným vyučujúcim zaradení do triedy, ktorá zodpovedala ich vedomostiam. V závislosti od usilovnosti, osobnostných predpokladov aj ambícií jednotlivých študentov mohlo potom štúdium na jezuitskom gymnáziu prebiehat bud' v uzuálnom časovom rámci šiestich rokov a v prípade akademických, resp. duchovných ambícií žiakov d’alej pokračovat'

\footnotetext{
${ }^{6}$ Pozri MINÁRIK, J. Baroková literatúra svetová, česká, slovenská, s. 134.

${ }^{7}$ Pozri POLEHLA, P. Jezuitské divadlo ve službě zbožnosti a vzdělanosti. Červený Kostelec : Pavel Mervart, 2011, s. $43-123$.

${ }^{8}$ Počas štúdia totiž žiaci zvykli vyvádzat najrôznejšie eskapády, ktorým sa jezuitská školská prax usilovala predchádzat aj v rámci rádových kompendií, obsahujúcich popri inom tiež pregnantné metodické usmernenia pre pedagógov. Tí sa napríklad bežne stretávali so situáciou, že (účinkujúci) študenti priniesli v deň divadelného predstavenia do školy víno, ktorým však častokrát "zabudli“ obdarovat pracovníkov gymnaziálneho, resp. univerzitného divadla. Pozri Commentarii in Litteras Humaniores, s. 116 - 118. OSZK, Quart. Lat. 3271. Uvedené číslovanie zodpovedá tlačenej numerácii v archívnom dokumente. Za kritický preklad latinských, resp. neolatinských prameňov autor tejto štúdie d’akuje Eme Pavlákovej, Alexandre Dekanovej a Martine Daubravovej, ktoré patria k eminentným konzultantkám autorovho doterajšieho výskumu a publikovaných štúdií.
} 
prinajmenšom trojročným štúdium na filozofickej fakulte a štvorročným štúdium na teologickej fakulte tej-ktorej univerzity Spoločnosti Ježišovej, alebo ho mladíci zanechávali podstatne skôr, napríklad po absolvovaní štyroch nižších gramatických tried. To ich však v bežnom živote profesijne nijako nediskvalifikovalo a spravidla sa uplatňovali ako kvalifikovaní úradníci. ${ }^{9}$

Tí, ktorí sa rozhodli pre kňazské povolanie a chceli ho vykonávat’ ako príslušníci jezuitského rádu, zvyčajne vstupovali do noviciátu pred nástupom na filozofickú fakultu rádovej univerzity, ešte ako študenti rétoriky (t. j. najvyššej triedy gymnázia). Noviciát trval dva roky a novitii (novici) museli počas tohto obdobia absolvovat' šest' praktických skúšok z rôznych oblastí rehol’ného života. V praxi sa však často stávalo, že skúšky boli rozlične modifikované a presúvané na dobu po dokončení štúdia na filozofickej fakulte. Noviciát $\mathrm{v}$ takomto prípade zakončovala séria duchovných cvičení, generálna spoved' a zloženie jednoduchých sl’ubov - chudoby, čistoty a poslušnosti. Takto sa z mladíkov stávali scholastici, ktorí bud' bezprostredne nastupovali na univerzitné štúdiá, alebo najskôr navštevovali tzv. repetentia humaniorum - opakovací kurz rétoriky či gymnaziálneho učiva, súvisiaci predovšetkým s ich prípravou na neskoršiu pedagogickú prax. Po absolvovaní filozofickej fakulty a spomínaných skúšok dosahovali mladí jezuiti užšiu spätost’ s rádom ako scholastici approbati (prijatí scholastici). Ich následné štvorročné štúdium na teologickej fakulte ukončovalo vysvätenie za kňaza, po ktorom im bola za predpokladu splnenia všetkých príslušných podmienok (vek dvadsat’ät' rokov a desat' rokov strávených v ráde) umožnená tretia probácia („druhý noviciát“). Trvala zvyčajne jeden rok a vrcholila zložením štyroch večných slubov - poslušnosti, čistoty, chudoby a poslušnosti voči pápežovi. Podl’a českej historičky a filologičky Kateřiny Bobkovej-Valentovej sa týmto jej absolventi - patres (otcovia), resp. Nostri (Naši) - stávali v rámci hierarchie Spoločnosti Ježišovej akousi rádovou elitou. ${ }^{10}$

Popri zvládnutí uvedených povinností predstavovala v procese postupného pridružovania jednotlivcov k rádu nevyhnutný záväzok aj ich pedagogická služba na jezuitských gymnáziách. Ako zdôrazňuje Bobková-Valentová, všetci jezuiti ňou v praxi prešli minimálne dva razy: prvýkrát po dokončení štúdia na filozofickej fakulte (po ňom v štúdiu na teologickej fakulte priamo pokračovali len tí najtalentovanejší) a druhýkrát po ukončení teológie, v období pred prípravou na zloženie štyroch večných sl’ubov. Absolventi filozofickej fakulty vyučovali v štyroch nižších (gramatických) triedach rádových gymnázií. V niektorých prípadoch boli mimoriadne nadaní scholastici approbati poverení aj výučbou v dvoch vyšších triedach (t. j. poetickej a rétorickej), no inak $\mathrm{v}$ nich spravidla pedagogicky pôsobili absolventi teologickej fakulty. ${ }^{11}$

${ }^{9}$ Pozri BOBKOVÁ-VALENTOVÁ, K. Každodenní život učitele a žáka jezuitského gymnázia. Praha : Karolinum, 2006, s. $61-71$.

${ }^{10}$ Pozri tamže, s. $9-10$.

${ }^{11}$ Za vhodný príklad tejto uzancie na území dnešného Slovenska možno označit pôsobenie významného slovenského historika, zástancu uplatňovania kritickej historiografie v Uhorskom královstve, Samuela Timona (1675 - 1736) na Trnavskej univerzite, ktorá po svojom vzniku v roku 1635 predstavovala viac ako dve dekády jedinú univerzitu v celom Uhorsku. Po absolvovaní dvojročného noviciátu (pravdepodobne vo Viedni) a ročnom učitel’skom pôsobení v Skalici nastúpil Timon v roku 1696 ako odchovanec bratislavského gymnázia na filozofickú fakultu Trnavskej univerzity, kde v roku 1699 štúdium zakončil magisterskými skúškami. Tie sa na Trnavskej univerzite do roku 1753 konali bud' v júni alebo v júli, a po nich v auguste nasledovali promócie majúce charakter obhajoby, pričom úspešným absolventom sa udel'oval titul artium libe- 
S penzom učiva (najmä z gramatiky, poetiky a rétoriky), ktoré mali profesori svojim žiakom v rámci výučby na gymnáziách sprostredkovat', boli jezuitskí pedagógovia podrobne oboznámení na základe opakovacieho kurzu repetentia humaniorum, ktorý viacerí z nich absolvovali ešte pred nástupom na filozofickú fakultu. Východiskové učebnice týchto kurzov a následne bazálne metodické pomôcky pre vyučujúcich vo výchovno-vzdelávacom procese predstavovali - prinajmenšom v Rakúskej provincii Spoločnosti Ježišovej - bud' učitel'ské alebo študentské poznámky, majúce podobu rukopisných kompendií latinského jazyka a reálií. Ich súčastou boli v mnohých prípadoch aj dramatické poetiky, resp. state pojednávajúce o teórii drámy. Tieto kapitoly vznikali ako kompiláty z najvýznamnejších tlačených jezuitských poetík, na ktoré takmer vždy odkazovali uvedením nielen názvu, ale aj čísla príslušnej strany toho-ktorého literárno-teoretického diela. Bežne obsahovali i vzorové drámy, no nie v celom rozsahu, ale vo forme stručného obsahu ich prológu, jednotlivých dejstiev, medzidejstvových intermédií a epilógu - teda v podobe perioch (dobových „bulletinov“). Na našom území bol spomínaný opakovací kurz zriadený v roku 1734 v rámci skalického vzdelávacieho inštitútu s názvom Collegium repetentium humaniorum, ktorý až do roku 1742 reprezentoval jediný ústav svojho druhu v Uhorsku. ${ }^{12}$

V kontexte explikácie špecifík jezuitskej teórie drámy etablovanej na území dnešného Slovenska v období baroka teda môžeme zástoj skalického kolégia Spoločnosti Ježišovej v dejinách nášho rádového divadelníctva označit’ za dominantný. Obzvlášt', ak vezmeme do úvahy skutočnost', že v prvej polovici, resp. najneskôr na sklonku 18. storočia vznikli v Skalici pravdepodobne až štyri takéto kompendiá, z ktorých každé obsahovalo aj kapitolu týkajúcu sa teórie drámy. ${ }^{13}$

Autorstvo najstaršieho z týchto prameňov, vytvoreného v roku 1734 a v súčasnosti umiestneného v Univerzitnej knižnici a archívoch Univerzity Loránda Eötvösa v Budapešti pod signatúrou F 33, patrí miestnemu učitelovi latinského jazyka a poetiky menom Antonius Hellmayr (1700 -1744), ktorý sa po trojročnom pôsobení

ralium et philosophiae magister (magister slobodných umení a filozofie), skrátene AA. LL. Mag. Timonovo následné pedagogické pôsobenie v tretej a štvrtej triede trnavského šestttriedneho jezuitského gymnázia (1. Majores parvistae, 2. Principistae, 3. Grammatistae, 4. Syntaxistae, 5. Poetae, 6. Retores), ktoré so svojou trojtriednou prípravkou (1. Minimistae, 2. Declinistae, 3. Minores parvistae) spadalo pod názvom facultas linguarum (fakulta jazykov) do inštitucionálnej sústavy filozofickej fakulty Trnavskej univerzity, vymedzujeme rokmi 1699 - 1702. Pred svojím nástupom na teologickú fakultu Timon v rokoch 1702 - 1704 taktiež vyučoval v piatej a šiestej triede prešovského (možno aj levočského) gymnázia. Po absolvovaní teológie v Trnave sa opät’ vrátil na miestne gymnázium, kde bol v rokoch 1707 - 1708 triednym učitelom najvyššej (šiestej) triedy. V kontexte Timonovho pôsobenia v meste Trnava je potrebné spomenút i jeho pedagogické aktivity na samotnej Trnavskej univerzite, kde v rokoch 1712 - 1719 prednášal hebrejčinu, etiku, fyziku, filozofiu či morálku. Zároveň nemožno opomenút’ ani jeho pozíciu dekana (Łzn. riaditela) trnavského jezuitského gymnázia, ktorú zastával v rokoch 1715, 1717 a 1718. Pozri BOBKOVÁ-VALENTOVÁ, K. Každodenní život učitele a žáka jezuitského gymnázia, s. 62 - 63; tiež MARSINA, R. Samuel Timon a Trnavská univerzita. In Trnavská univerzita 1635 - 1777 : 1. Referáty zo seminára $k 360$. výročiu založenia. 2. Príspevky z cirkevných dejín Slovenska. (Ed. J. Šimončič). Trnava : Trnavská univerzita, 1997, s. 209 - 212; tiež MARSINA, R. Filozofická fakulta 1635 - 1777. In Dejiny Trnavskej univerzity 1635 - 1777, 1992 - 2010. (Ed. J. Šimončič, A. Hološová). Trnava : Typi Universitatis Tyrnaviensis, 2010, s. 66 - 69.

12 Pozri PINTÉR, M. Z. Theatrum és literatúra. Budapest : Universitas Könyvkiadó, 2014, s. 81 - 82. Za odborný preklad podkapitoly Kéziratos drámapoétikák a 17 - 18. századból autor tejto štúdie d’akuje Galine Sándorovej.

${ }^{13}$ Rezultáty minucióznej analýzy dramatických poetík všetkých štyroch rukopisov publikovala v roku 2014 Márta Zsuzsanna Pintér vo svojej monografii Theatrum és literatúra. Pozri PINTÉR, M. Z. Theatrum és literatúra, s. $81-89$. 
v Skalici stal pedagógom na Trnavskej univerzite, kde vyučoval filozofiu. Jeho práca (skrátene) Institutio in Litteras Humaniores (Vyučovanie humanitných vied) ${ }^{14}$ obsahuje v rámci detailnej literárno-teoretickej časti aj štyridsat’stranový ikonologický záznam s podrobným opisom kostýmov a rekvizít vyše sto alegorických postáv, vyhotovený na základe Ripovho diela Iconologia z roku 1593. Jej súčastou je aj zoznam odporúčanej literatúry, v ktorom sa popri menách a dielach významných dramatikov i historikov spomínajú tiež teoretické diela, ktorých autormi sú Georgius Fabricius, Alessandro Donatus, Bohuslav Balbinus, Joseph de Jouvency, Martin du Cygne, Antonius Forti či Jacobus Masenius. ${ }^{15}$

Autora a rok vzniku druhého skalického kompendia s názvom Commentarii in Litteras Humaniores (Poznámky k humanitným vedám) nepoznáme. Podobne ako Hellmayrov rukopis je aj tento prameň súčastou zbierok Univerzitnej knižnice a archívov Univerzity Loránda Eötvösa v Budapešti (signatúra F 37). Od Hellmayrovej práce sa obsahový rámec jeho dramatickej poetiky odlišuje iba rozšíreným zoznamom odporúčanej literatúry. Spomedzi autorov z 18. storočia v ňom nájdeme napríklad mená Pietra Metastasia, Johanna Christopha Gottscheda či Ludviga Holberga. Na základe toho mad’arská literárna a divadelná historička Márta Zsuzsanna Pintér predpokladá, že kompendium sa v skalickom vzdelávacom inštitúte používalo o jednu alebo dve dekády neskôr než Hellmayrov rukopis. ${ }^{16}$

Zo Skalice s najväčšou pravdepodobnostou pochádza aj tretie, anonymné rukopisné kompendium. Jeho názov Commentarii in Litteras Humaniores a jeho umiestnenie v príslušnej budapeštianskej knižnici (signatúra F 38) sa zhoduje s predošlými prameňmi. $V$ porovnaní s nimi však kapitola venovaná teórii drámy vykazuje markantné rozdiely a absentuje v nej zoznam odporúčanej literatúry. Zo vzorových diel, resp. autorov (dramatikov, historikov a teoretikov) sa v nej spomínajú iba Plautus, Terentius, Seneca, Publius Flavius Vegetius Renatus, Charles de la Rue, Jacob Bidermann, Molière, Lawrence Beyerlinck, Laurentius Surius, Pedro de Ribadeneira či Carlo Casalicchio. Aj napriek tejto skutočnosti je Pintérová presvedčená, že rukopis evidentne ovplyvnili takmer všetci jezuitskí autori zo 17. storočia. Prameň taktiež obsahuje periochu vzorovej drámy s názvom Joannes Gualbertus (Ján Gualbert), ktorá bola predvedená v Trnave v roku 1650. Ked’že tento rukopis upravovalo viacero osôb, za štvrté doteraz známe kompendium skalickej proveniencie možno označit jeho čistopis s rovnomenným názvom Commentarii in Litteras Humaniores ${ }^{17}$, ktorý je

${ }^{14} \mathrm{~V}$ slovenskej historiografii sa komplexnejším rozborom Hellmayrovej práce zaoberal Július Sopko v štúdii Dobová latinská jazyková kultúra na školách a Trnavská univerzita (1986), no analýze dramatickej poetiky rukopisu v nej venoval len marginálny priestor. V rovine elementárneho priblíženia zoznamu odporúčanej literatúry daného prameňa referovala v roku 2006 o Hellmayrovej práci (v nadväznosti na rezultáty Júliusa Sopka) aj Miriam Poriezová v štúdii Ad usum juventutis : jazyková literatúra vo vydavatel'skom programe trnavskej Akademickej tlačiarne (1648 - 1773). Pozri SOPKO, J. Dobová latinská jazyková kultúra na školách a Trnavská univerzita. In Trnavská univerzita v dejinách školstva a vzdelanosti : zborník referátov vedeckej konferencie konanej v Bratislave dňa 26. novembra 1985 pri príležitosti 350. výročia založenia Trnavskej univerzity. (Ed. M. Novacká). Bratislava : Slovenská pedagogická knižnica, 1986, s. 93 - 98; tiež PORIEZOVÁ, M. Ad usum juventutis : jazyková literatúra vo vydavatel'skom programe trnavskej Akademickej tlačiarne (1648 - 1773). In Studia bibliographica Posoniensia I/2006. (Ed. M. Poriezová). Bratislava : Univerzitná knižnica, 2006, s. 134.

${ }^{15}$ Pozri PINTÉR, M. Z. Theatrum és literatúra, s. 83 - 85.

${ }^{16}$ Pozri tamže, s. 85.

${ }^{17}$ Bol to práve Ladislav Kačic, kto v nadväznosti na zmienku M. Z. Pintér o existencii tohto historického prameňa z roku 1993 vo svojej štúdii Jezuitská školská hra, hudba a tanec (1998) ako prvý upozornil slovenských bádatelov na význam samotného čistopisu. V štúdii Jezuitská školská hra a hudba na Slovensku v 17. - 18. 


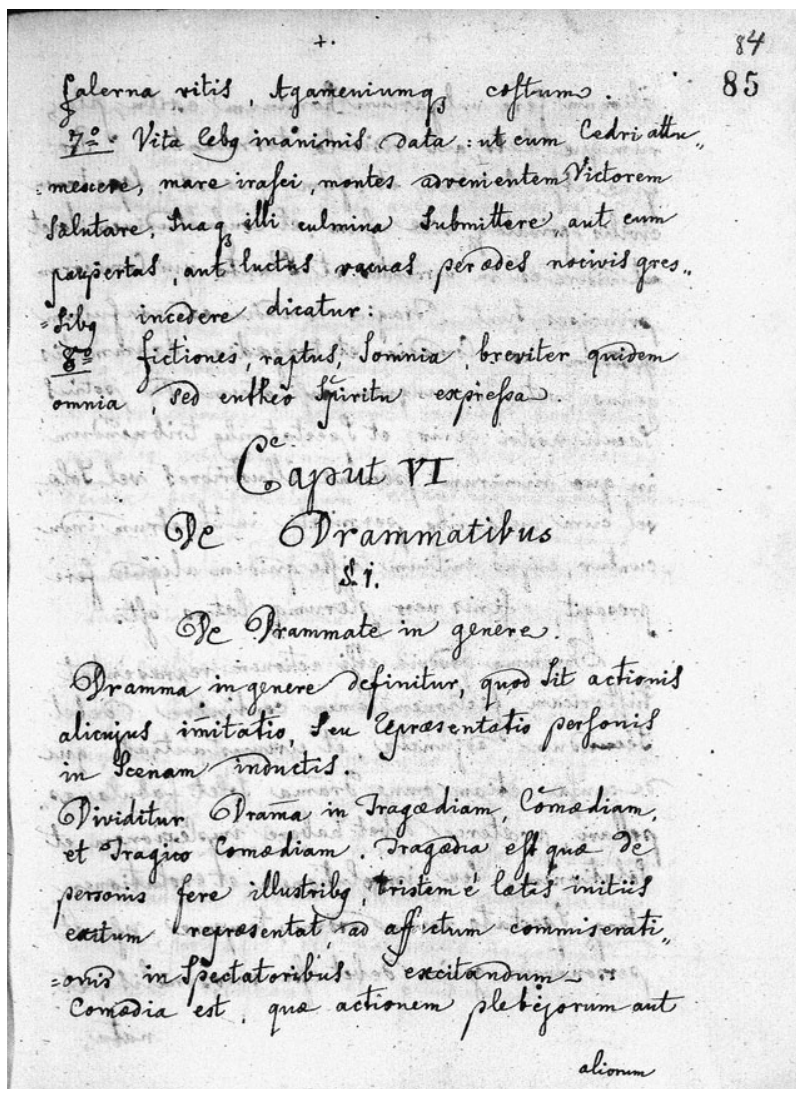

Úvodná strana šiestej kapitoly

De Drammatibus (O drámach)

druhého traktátu De Poësi

in Specie (O poézii podrobnejšie)

druhej časti Observationes

Poëticae (Postrehy o básnickom

umení) čistopisu kompendia

Commentarii in Litteras

Humaniores (Poznámky

k humanitným vedám). Zdroj

Országos Széchényi Könyvtár,

Budapest, Quart. Lat. 3271.

pod signatúrou Quart. Lat. 3271 uložený v Národnej Széchényiho knižnici v Budapešti. ${ }^{18}$

Podla Pintérovej ponúka spomedzi spomínaných skalických kompendií najviac informácií o jezuitskom školskom divadelníctve práve literárno-teoretická čast’ rukopisu Commentarii in Litteras Humaniores, ktorého čistopis sa nachádza v Národnej Széchényiho knižnici v Budapešti ${ }^{19}$ Ak zohl'adníme jej tézu, tak sa nám v intenciách našej ambície vymedzit’ mieru uplatňovania teoretických východísk najvýznamnejších jezuitských dramatických poetík v rádovej dramaticko-divadelnej praxi na území dnešného Slovenska v období baroka a zároveň preklenút ruptúru v kontinuite domáceho výskumu uvedeného prameňa javí ako opodstatnená konfrontácia

storoči (2006) následne pokračoval v jeho podrobnejšej analýze, a to predovšetkým vo vztłahu k fenoménu hudby a tanca v barokových jezuitských školských hrách na území dnešného Slovenska. Pozri PINTÉR, M. Z. A ferences iskolai színjátszás a 18. században. Budapest : Argumentum Kiadó, 1993, s. 68; tiež KAČIC, L. Jezuitská školská hra, hudba a tanec. In Slovenské divadlo, 1998, roč. 46, č. 1, s. 33 - 42; tiež KAČIC, L. Jezuitská školská hra a hudba na Slovensku v 17. - 18. storočí. In Jezuitské školstvo včera a dnes : zborník z medzinárodnej vedeckej konferencie 12. októbra 2006 v Trnave, s. 175 - 188.

${ }^{18}$ Pozri PINTÉR, M. Z. Theatrum és literatúra, s. 85 - 86; tiež Commentarii in Litteras Humaniores, s. 85 - 94. OSZK, Quart. Lat. 3271.

${ }^{19}$ Pozri PINTÉR, M. Z. Theatrum és literatúra, s. 85. 
teoretických rámcov state De Drammatibus (O drámach) so sujetom jednej z našich najreprezentatívnejších jezuitských školských hier, tragédie Moyses (Mojžiš) ${ }^{20} \mathrm{z}$ roku 1749, ktorej sa v odbornej slovenskej literatúre doposial' nedostalo výraznejšej pozornosti. ${ }^{21}$

„Nech je to k dobru, štastiu, blahu a zdaru a nech to prispeje k sláve Boha trikrát najväčšieho, najlepšieho, $\mathrm{k}$ väčšiemu okrášleniu cti a vzrastu tejto dobrotivej univerzity! Vđ’aka cisárskej štedrosti najvznešenejšej cisárovnej Márie Terézie, královnej Uhorska, Čiech, arcivojvodkyne Rakúska, vojvodkyne Štajerska, zaslúžili si byt’ odmenení (...).“22 Pravdepodobne po týchto slávnostných slovách predstúpili v auguste 1749 $\mathrm{v}$ aule Trnavskej univerzity alebo $\mathrm{v}$ trnavskom univerzitnom kostole pred promótora čerství absolventi filozofickej fakulty, aby si prevzali svoje magisterské diplomy z filozofie a aby boli vzápätí študentmi rétorickej triedy jezuitského gymnázia obdarovaní promočným darom v podobe knižky ${ }^{23} \mathrm{~s}$ kompletným textom tragédie Moyses.

Túto náboženskú pätdejstvovú školskú drámu Jozefa Bartakoviča (1722 - 1763), pochádzajúceho z obce Sokolníky (dnešné Podhorany), ktorý na trnavskom gymnáziu pôsobil v rokoch 1746 - 174924, predviedli pri príležitosti blížiaceho sa konca školského roka 15. júla 1749 vo vel'kej divadelnej sále trnavského univerzitného divadla $^{25}$ nielen žiaci všetkých gymnaziálnych tried, ale aj študenti viacerých fakúlt Trnavskej univerzity. ${ }^{26} \mathrm{Z}$ početného obsadenia školskej hry sa v perioche, resp. v jej záverečnom zozname účinkujúcich študentov nachádzajú iba mená štyroch spomedzi deviatich obdarovávajúcich rétorov. Adamus de Koermend stvárnil v inscenácii postavu jedného zo šiestich popredných egyptských mužov, Josephus Gullik de Ea-

\footnotetext{
${ }^{20}$ Markantný dobový význam tejto tragédie potvrdzuje aj fakt, že patrí do minoritnej skupiny štyroch doteraz známych trnavských školských hier z prvej polovice 18. storočia, ku ktorým bola vo vydavatel'stve, resp. kníhtlačiarni Trnavskej univerzity vydaná nielen periocha (v súčasnosti umiestnená pod signatúrou KNY_18_00967 v Univerzitnej knižnici a archívoch Univerzity Loránda Eötvösa v Budapešti), ale aj kompletný text (nachádzajúci sa v Národnej Széchényiho knižnici v Budapešti pod signatúrou 319.146). Pozri STAUD, G. A magyarországi jezsuita iskolai színjátékok forrásai I. 1561-1773. Budapest : A Magyar Tudományos Akadémia, 1984, s. 120 - 198.

${ }^{21}$ Podrobnejšie sa tragédiou zaoberal Ladislav Kačic, a to najmä v súvislosti s jej rozsahom, obsadením a podielom hudby v nej. Pozri KAČIC, L. Jezuitská školská hra a hudba na Slovensku v 17. - 18. storočí. In Jezuitské školstvo včera a dnes : zborník z medzinárodnej vedeckej konferencie 12. októbra 2006 v Trnave, s. 183.

${ }^{22}$ Prepis pôvodného latinského znenia oficiálnej promočnej formuly Trnavskej univerzity z 18. storočia publikovala v roku 2010 Zuzana Droběnová v kolektívnej publikácii Dejiny Trnavskej univerzity 1635 - 1777, 1992 - 2010. Pozri DROBĚNOVÁ, Z. Študenti a profesori. In Dejiny Trnavskej univerzity 1635 - 1777, $1992-2010$, s. 171.

${ }^{23}$ Popri promujúcich boli spravidla obdarovávaní aj čestní hostia promócií, ktorým sa zvykli rozdávat nielen knižky, ale i rukavice, katalógy, prípadne básne. Pozri tamže, s. 171.

${ }^{24}$ Pozri ALSZEGHY, Z. - BERECZ, Á. - KERESZTES, A. - KISS, K. - KNAPP, É. - VARGA, I. Jezsuita iskoladrámák: (ismeretlen szerzők) programok, színlapok. Budapest : Akadémiai Kiadó - Argumentum Kiadó, 1995, s. 1057.

${ }^{25}$ Pozri STAUD, G. A magyarországi jezsuita iskolai színjátékok forrásai I. 1561 -1773, s. 190.

${ }^{26}$ Pri tomto konštatovaní sa opierame o zoznam účinkujúcich študentov, ktorý sa nachádza v závere tlačenej periochy tragédie a ktorý je v jej kompletnom tlačenom texte nahradený menoslovom deviatich frekventantov rétorickej triedy trnavského gymnázia. Z tohto zoznamu sa dozvedáme, že v inscenácii účinkovali popri študentoch filozofickej a teologickej fakulty aj piati študenti právnickej fakulty a devät študentov Mariánskeho seminára. Už predošlý výskum Ladislava Kačica poukázal na skutočnost’, že na predvedení tragédie participovalo vyše 150 účinkujúcich. Pozri Moyses. Tyrnaviae : Typis Academicis, 1749, s. 20 - 23. ELTE EKL, KNY_18_00967; tiež Moyses. Tyrnaviae : Typis Academicis, 1749, s. 63 - 64. OSZK 319.146; tiež KAČIC, L. Jezuitská školská hra a hudba na Slovensku v 17. - 18. storočí. In Jezuitské školstvo včera a dnes : zborník z medzinárodnej vedeckej konferencie 12. októbra 2006 v Trnave, s. 183.
} 
M O Y S E S

NUPER ACTA

acting

A CADEMICIS

GNUNCOBLATA

ILlUStRissimis SPECTABILIBUS,

Perillustribus, Reverendis

PRENOBILIBUS NoBILIBUS,

EXCELLENTIBUS, AC DOCTISSIMIS DD. AA. TL. ET PHILOSOPHIE

MA GTSTRIS

a Perillustrt, Pranobili, Nobili

R H E T H O I C A

CRSTRNAVIENSI

R.P.NICOLAUM SCHMITTH, $\%$

AA. LL. \& Philor. Doctorem nec non in

Alma ac Celeberrima Univ. Tyrnavienfi

Profefforem Emeritum

Suprema AA. LL. \& Philofophiæ laurę

condecorarentur

ANNO M.DCC. XLIX. Meife Aug. die

T Y R N A V I A,

TYPIS ACADEMICIS SOCIE'TRIS JESU.

Titulný list kompletného tlačeného textu tragédie Moyses (Mojžiš). Zdroj Országos Széchényi Könyvtár, Budapest, 319.146 . dem a Adalbertus Lipthay postavy dvoch (z celkového počtu šiestich) izraelských staršinov. Josephus Golboch sa $\mathrm{v}$ rámci skupiny alegorických postáv, ktoré vystupujú v prológu, štyroch medzidejstvových intermédiách a epilógu školskej hry, predstavil v role jedného zo šiestich morských bohov Tritónov. ${ }^{27}$

Aj ked' sa mená zvyšných piatich študentov príslušnej rétorickej triedy ${ }^{28} \mathrm{v}$ spomínanom zozname nenachádzajú, vzhladom na typ školskej hry môžeme predpokladat', že všetci $v$ inscenácii s najväčšou pravdepodobnostou účinkovali, a to bud' ako členovia komparzu faraónovho vojska alebo izraelského l'udu. ${ }^{29}$ Zodpovedalo by to aj Hellmayrovmu odporúčaniu, aby jezuitskí pedagógovia (autori a zároveň režiséri školských dramaticko-divadelných produkcií) obsadzovali múzicky menej nadaných študentov - bez ohl'adu na ich potenciálne vznešený pôvod - predovšetkým ako štatistov, prípadne im zverovali stvárnenie epizodických postáv. ${ }^{30}$

$\mathrm{V}$ už zmienenom promočnom dare, konkrétne v jeho úvodnej dedikácii, sa trnavskí rétori prihovárajú svojim starším kolegom slovami: „Najjasnejší, vážení, úctyhodní, najvznešenejší, vynikajúci a najučenejší páni magistri slobodných umení a filozofie. Páni noví doktori ${ }^{31}$, na Vašu počest' dnes predkladáme dielo Mojžiš o mužovi, ktorý v Egypte vykonal vel'ké zázraky. Nepochybujeme, že dovolíte, aby toto dielo sprevádzalo Vašu slávu, ved' aj vy sami ste boli jeho súčastou. Neslýchanú udatnost' tohto muža, odvahu prevyšujúcu všetky nebezpečenstvá a d’alšie cnosti Vám postupne počas troch rokov nakvapkávala Filozofia a vd’aka tejto knižke si ich vytlačené budete nosit’ so sebou. Kým budete tieto cnosti napodobňovat', nech vám

\footnotetext{
${ }^{27}$ Pozri Moyses. Tyrnaviae : Typis Academicis, 1749, s. 20 - 22. ELTE EKL, KNY_18_00967.

${ }^{28}$ Andreas Nebling, Casparus Spelak, Emericus Scsaszny, Joannes Kellner a Joannes Nepom. Palsovics

${ }^{29}$ Pozri Moyses. Tyrnaviae : Typis Academicis, 1749, s. 23. ELTE EKL, KNY_18_00967.

${ }^{30}$ Pozri PINTÉR, M. Z. Theatrum és literatúra, s. 83 - 84.

${ }^{31}$ Ak absolventi trojročného študijného cyklu na filozofickej fakulte zostali v službách univerzity, kde pôsobili na pozícii pedagógov, ich magisterský titul sa zvykol označovat' aj ako doktorát. Pozri DROBĚNOVÁ, Z. Študenti a profesori. In Dejiny Trnavskej univerzity 1635 - 1777, 1992 - 2010, s. 170.
} 
život poskytne tol'ko času, aby ste si mohli mysliet', že nemá žiaden koniec. Mojžišova cnost' dosiahla vrchol. Vel'kost' jeho ducha bola obdivuhodná a jeho neochvejnost’ v trestaní hanebností, ktorá sa filozofom vždy páčila, bola taká vel'ká, akú po ňom nik zo smrtel'níkov nemal. Možno uvidíte, že tento dar je hoden Vašej cnosti, o ktorú sa celým srdcom usilujete, ak zavadíte pohladom o argumentum ${ }^{32}$ krátke a stručné, ak zavadíte pohl'adom o samo dielo. Dúfame však, že vd’aka svojmu vzdelaniu budete uvažovat' viac o myšlienke, ktorá sa núka, než o samotnom deji, a ochotne si ju osvojíte, ako máte vo zvyku. ${ }^{\prime 33}$

Je to práve nevyhnutnost' cnosti ako - v náboženskom zmysle slova - trvalej dispozície konat' dobro, ktorá v mravoučnom presahu determinuje nielen odkaz daného venovacieho textu, ale i zámer vol'by námetu tragédie Moyses. ${ }^{34} \mathrm{~V}$ jej

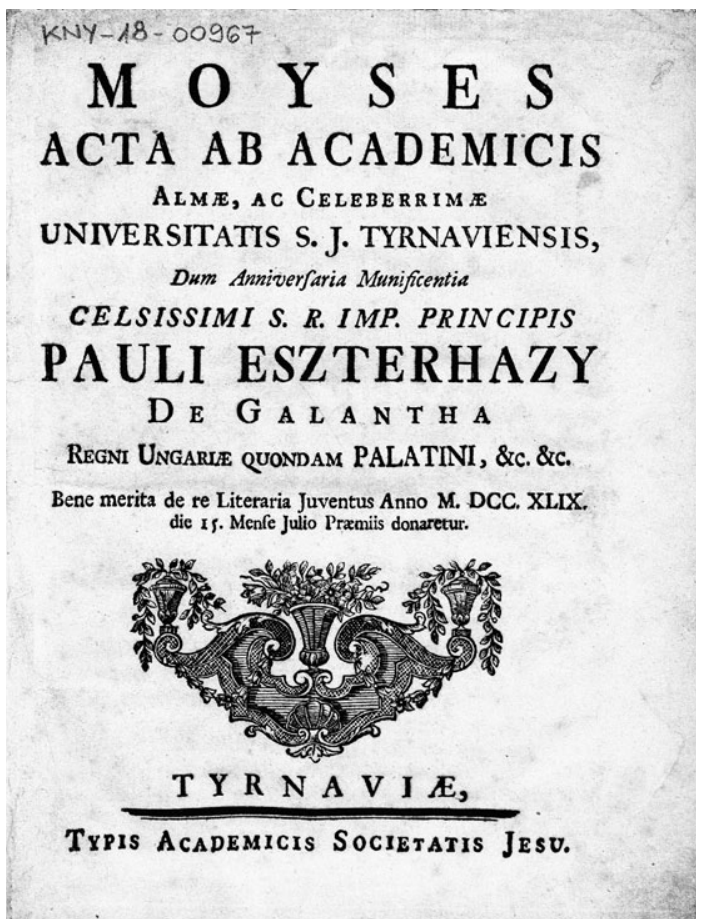

Titulný list tlačenej periochy tragédie Moyses (Mojžiš). Zdroj ELTE Egyetemi Könyvtár és Levéltár, Budapest, KNY_18_00967. sujete totiž Jozef Bartakovič za využitia básnickej licencie spracováva biblický opis udalostí štrnástej kapitoly Knihy Exodus, pričom v rámci jej fabuly túto biblickú naráciu reflektuje so spätným presahom až k piatej kapitole uvedeného zdroja námetu.

Autor teda v intenciách čistopisu kompendia Commentarii in Litteras Humaniores, totiž jeho state De Drammatibus a konkrétne jej podkapitoly De Inventione Drammatis (O tvorení drámy), zretel’ne uprednostňuje náboženský námet pred svetským, aby sa popri naplnení nábožensko-propagačných ambícii tragédie pokúsil aj o jej eventuálne mravné pôsobenie na účinkujúcich študentov a trnavské obecenstvo. Tým zároveň zohl'adňuje teoretický imperatív vyzdvihnutia cnosti v zmysle odvrátenia od jej opaku (hriechu) v sujete drámy, ktorý je akcentovaný v podkapitole De Elocutione Periochae (O štýle v perioche). ${ }^{35}$

\footnotetext{
${ }^{32}$ Viac o problematike stručných obsahov v štruktúre jezuitských perioch a kompletných tlačených textov pozri JACKOVÁ, M. Divadlo jako škola ctnosti a zbožnosti : jezuitské školské drama v Praze v proní polovině 18. století. Praha : Filozofická fakulta Univerzity Karlovy, 2011, s. 19.

${ }^{33}$ Pozri Moyses. Tyrnaviae : Typis Academicis, 1749, s. 3 - 4. OSZK 319.146.

${ }^{34}$ Elysamas (5. dejstvo, 2. scéna): „(...) Kadekol'vek sme šli, všade sa rozptyl’ovala vôňa balzamu a plnila celé priestranstvo. Nebola to vôňa ruží, ani škorice, ani balzamu. Bol to závan cností, ktorým svätá nevinnost kedysi navoňala tieto kosti. (...)." Pozri Moyses. Tyrnaviae : Typis Academicis, 1749, s. 50. OSZK 319.146.

${ }^{35}$ Porov. Moyses. Tyrnaviae : Typis Academicis, 1749. OSZK 319.146 a Commentarii in Litteras Humaniores, s. $88-90$ a $105-106$.
} 
V zhode s odporúčaniami podkapitoly De Inventione Drammatis si Bartakovič taktiež volí vel’mi známy biblický príbeh, zohrávajúci v krestanských dejinách spásy klúčovú úlohu. V danom kontexte autor rešpektuje aj radu spracovat cudzokrajný, starý námet namiesto súčasnej domácej tematiky, aby tak docielil maximálnu možnú mieru prirodzenosti fikcie. Tá by podl'a podkapitoly De Drammate in genere (O dráme všeobecne) mala byt’ obsiahnutá v každej dráme, ked’že predstavuje nevyhnutnú podmienku jej dramatickej zápletky, o čom podrobnejšie pojednávajú podkapitoly De Fictione, Involutione, et Evolutione Drammatis in genere (Všeobecne o fikcii, zápletke a rozuzlení v dráme) a De Fictione seu Evolutione, et Involutione in Specie (O fikcii alebo o rozuzlení a zápletke podrobnejšie). ${ }^{36}$

V súvislosti s d’alším usmernením podkapitoly De Inventione Drammatis, týkajúcim sa prispôsobenia námetu hercom, Bartakovičova drama majus nijako nevybočuje z predpísaného teoretického rámca čistopisu kompendia. Autor vzhladom na jej typologický charakter kreuje dramatické postavy (od hlavných cez vedlajšie až po epizodické) so zretel'om na ich následné stvárnenie študentmi v adekvátnom veku. V tomto prípade to boli frekventanti prvých troch ročníkov teologickej fakulty Trnavskej univerzity, d’alej poslucháči všetkých troch ročníkov filozofickej fakulty a napokon žiaci jednotlivých tried jezuitského gymnázia, od najvyšších po najnižšie. ${ }^{37}$ Navyše, v kontexte obsadenia komparzu faraónovej armády štyridsiatimi frekventantmi filozofickej fakulty, troma študentmi teologickej fakulty a dvoma poslucháčmi právnickej fakulty, ktorých velitel'ov stvárnili traja študenti filozofickej fakulty spolu s jedným frekventantom právnickej fakulty a žiakom piatej (poetickej) triedy trnavského gymnázia, Bartakovič taktiež zohl'adňuje požiadavku pravdepodobnosti dramatického deja školskej hry. ${ }^{38}$

Dramatický dej tragédie Moyses situuje autor do púšte pred Pí-hachirotom pri Červenom mori, konkrétne do Mojžišovho a faraónovho tábora, a vymedzuje ho trvaním dvadsiatich štyroch hodín. Hlavná dejová línia pät’dejstvovej školskej drámy, zachytávajúca predovšetkým konanie Mojžiša a jeho spoločníkov, je obsiahnutá v sujete druhého, tretieho, štvrtého a piateho dejstva tragédie a determinuje ju biblická narácia desiateho až tridsiateho prvého verša štrnástej kapitoly Knihy Exodus. Vedl'ajšiu dejovú líniu, zachytávajúcu konanie faraóna a jeho spoločníkov, obsahuje sujet prvého dejstva tragédie, ktorého východiskový dramatický rámec ohraničuje biblický opis udalostí prvého až deviateho verša rovnakej kapitoly tzv. druhej knihy Mojžišovej. Bartakovič teda komponoval dramatický dej tragédie Moyses v plnom súlade s príslušnými teoretickými východiskami podkapitoly De Inventione Drammatis, tzn. vyzdvihujúc jednu (dominantnú) dejovú líniu, ktorá sa odohráva na jednom mieste a v priebehu jedného dňa. ${ }^{39}$

Z obsahového rámca podkapitoly De Drammate in genere vyplýva, že naratívne usporiadanie dramatického deja ovplyvňujú protichodné činy protagonistov a anta-

\footnotetext{
${ }^{36}$ Porov. Moyses. Tyrnaviae : Typis Academicis, 1749. OSZK 319.146 a Commentarii in Litteras Humaniores, s. $85-100$.

${ }^{37}$ Porov. Moyses. Tyrnaviae : Typis Academicis, 1749, s. 20 - 23. ELTE EKL, KNY_18_00967 a Commentarii in Litteras Humaniores, s. 88.

${ }^{38}$ Porov. Moyses. Tyrnaviae : Typis Academicis, 1749, s. 21 - 22. ELTE EKL, KNY_18_00967 a Commentarii in Litteras Humaniores, s. $85-86$.

${ }^{39}$ Porov. Moyses. Tyrnaviae : Typis Academicis, 1749. OSZK 319.146 a Commentarii in Litteras Humaniores, s. $89-90$.
} 
gonistov. Tie nielenže bezprostredne ústia do dramatického konfliktu, ktorý uvádza dej do pohybu, ale taktiež napomáhajú pri vytváraní jeho zápletky. A práve zápletka (spolu s rozuzlením) predstavuje v kontexte predpisov dramatickej poetiky čistopisu Commentarii in Litteras Humaniores jednu z najdôležitejších podmienok každého dramatického deja. To sa prejavuje najmä vo vzţahu $\mathrm{k}$ jeho vnútornej diferenciácii na prothasis (úvodná čast̉ deja obsahujúca základ zápletky), epithasis (následná čast’ deja, v ktorej sa zápletka d’alej rozvíja a v ktorej sa objavujú explicitné dramatické konflikty), catastasis (tá čast’ deja, v ktorej sa všetko dianie zastaví na vrchole ústredného dramatického konfliktu, čo má za následok pomyselnú bezvýchodiskovost’ daného stavu) a catastrophe (záverečná čast’ deja, pre ktorú je príznačné rozuzlenie vyplývajúce $\mathrm{z}$ nečakaného, rozhodujúceho zvratu). ${ }^{40}$

Ako sme už naznačili na predošlom mieste, teoretické odporúčania kompendia v súvislosti s vytváraním zápletky zdôrazňujú, že ju do dramatického deja treba pridał’ predovšetkým za využitia fikcie (ked’že potenciálna imanentná zápletka akéhokolvek historického námetu v dráme nepostačuje ${ }^{41}$, pričom jej nevyhnutnou súčastou má byt' podla podkapitoly De Fictione, Involutione, et Evolutione Drammatis in genere nečakané spoznanie nejakej veci alebo osoby predtým nespoznanej a taktiež nečakaný zvrat. ${ }^{42}$

Úvodná čast' prothasis $\mathrm{v}$ dramatickom deji tragédie Moyses zodpovedá sujetu prvého dejstva pozostávajúceho z piatich scén. Východisko dramatickej zápletky tu predstavujú dva rozhodujúce okamihy. Prvým z nich je zajatie Elysama, ktorý sa na Mojžišov príkaz vydáva do púšte, aby v nej našiel sväté ostatky patriarchu Jozefa, pri čom ho zadrží velitel’ egyptského vojska Amasis. ${ }^{43}$ Druhým je moment, ked’ sa do faraónovho vojenského tábora z výzved vráti egyptský veštec Memnon a faraónovmu zatovi Lykofronovi a jeho spoločníkom (Mamylas, Akron a Akorus) oznámi údajné proroctvo Mojžiša o prinavrátení zavraždených prvorodených synov tým Egyptanom, ktorí sa pridajú k Izraelitom počas ich putovania do Kanaánu.

Čast' epithasis v dramatickom deji školskej drámy rámcuje sujet jej druhého a tretieho dejstva, zhodne pozostávajúcich z piatich scén. Rozvinutie prvotnej zápletky v tejto časti determinujú dva klúčové momenty. Jedným z nich je príchod Lykofrona a jeho spoločníkov do tábora Izraelitov, ked’že uverili údajnému Mojžišovmu proroctvu. Jeho výsledkom sú dve nečakané spoznania a z nich vyplývajúci zvrat. Prvú z dvoch spomínaných anagnoríz tvorí okamih, ked’ sa Egyptania od Mojžiša dozvedajú, že jeho proroctvo pochopili nesprávne, druhú zase okamih, ked’ sklúčený Ma-

${ }^{40} \mathrm{~V}$ uvedenej súvislosti môžeme s istotou konštatovat', že zostavenie príslušnej pasáže podkapitoly $D e$ Drammate in genere bezprostredne ovplyvnilo dielo Alexandra Donata s názvom Ars poetica (Básnické umenie), v ktorom autor ako jeden zo spôsobov členenia tragédie uvádza totožnú uzanciu. Porov. Commentarii in Litteras Humaniores, s. 86 - 87 a DONATUS, A. Ars poetica. Venetiis : Sumptibus Combi, \& Lanovii, 1684, s. $319-321$.

${ }^{41}$ Pozri Commentarii in Litteras Humaniores, s. 90.

${ }^{42} \mathrm{~V}$ aristotelovskom zmysle slova anagnoríza a peripetia. Porov. Commentarii in Litteras Humaniores, s. 90 - 91 a ARISTOTELES. Poetika. Martin : THETIS, 2009, s. 26 - 29.

${ }^{43} \mathrm{~V}$ kontexte teoretických východísk podkapitoly De Fictione, Involutione, et Evolutione Drammatis in genere zohl'adňuje pridanie tejto postavy do dramatického deja tragédie možnost’ využit pri umeleckej tvorbe popri fikcii v súlade s históriou, v ktorej by úpravy postáv a záveru deja mali byṫ čo najväčšmi podriadené samotnej histórii, aj fikciu v protiklade s históriou, ktorá by mala menit’ niečo, čo sa stalo, či skôr pridávat niečo, o čom sa vie, že sa nestalo. V tomto prípade daná fikcia mení biblickú naráciu devätnásteho verša trinástej kapitoly Knihy Exodus: „Mojžiš vzal so sebou Jozefove kosti. (...).“ Pozri Commentarii in Litteras Humaniores, s. 90 - 92; tiež Komentáre k Starému zákonu 3 : Exodus. (Ed. Jozef Tiňo). Trnava : Dobrá kniha, 2013, s. 346. 
mylas prezrádza Mojžišovi, že Elysama drží faraón v zajatí. Následná peripetia má podobu Mojžišovho príkazu uväznit’ Lykofrona a jeho spoločníkov. Ďalší zásadný moment rozvíjajúci počiatočnú dramatickú zápletku v epithasis predstavuje rozhodnutie Mojžiša vydat' sa do egyptského tábora za faraónom, aby odtial' vyslobodil Elysama, bez ktorého - a to najmä pre sväté ostatky patriarchu Jozefa - nemôžu Izraeliti pokračovat’ v putovaní do Kanaánu. K dvom epizódnym momentom v uvedenej časti dramatického deja, určeným skôr pre ozvláštnenie než rozvinutie zápletky (resp. pre vytvorenie akejsi vedl'ajšej dramatickej zápletky), patrí vzbura Koracha, Datána a Abiróna ${ }^{44}$, ako aj lest' egyptských mágov Jannesa a Mambresa, ktorí faraónovi vnuknú myšlienku, aby Mojžišovi, Áronovi a Elysamovi nedovolil odíst' z egyptského tábora, pokým oni v prezlečení za Mojžiša (Jannes) a Árona (Mambres) neprivedú Izraelitov spät’ do Egypta.

Čast' catastasis v dramatickom deji tragédie vymedzuje sujet jej štvrtého dejstva pozostávajúceho z piatich scén. V tejto časti vrcholí dramatický konflikt medzi Mojžišom a faraónom, ktorý odmieta prepustit’ Elysama a zároveň sa usiluje Mojžiša spolu s Áronom uväznit'. Bezvýchodiskovost' danej situácie, vyplývajúca zo samotného zenitu ústrednej zápletky, napokon bezprostredne ústi do d’alšej anagnorízy - do faraónovho zistenia, že jeho zat' Lykofron je Mojžišovým zajatcom a v prípade, ak sa Izraeliti nevrátia do tábora najneskôr na sklonku daného dňa, čaká ho spolu s jeho spoločníkmi smrt'. Výsledkom tohto nečakaného spoznania je peripetia v podobe prepustenia Mojžiša, Elysama a Árona, ktorú môžeme označit’ za rozhodujúcu, najmä pokial' ide o rozuzlenie v záverečnej časti dramatického deja tragédie.

Popri anagnoríze ${ }^{45}$ a peripetii ${ }^{46}$ vedlajšej dramatickej zápletky obsahuje catastrophe, zodpovedajúca sujetu piateho dejstva tragédie pozostávajúceho zo siedmich výstupov, rozuzlenie, ktoré plne rešpektuje biblickú naráciu dvadsiateho prvého až tridsiateho prvého verša štrnástej kapitoly Knihy Exodus, tzn. zostavené autorom za využitia fikcie v súlade s históriou.

Na základe uvedenej explikácie špecifík dramatického deja tragédie Moyses môžeme konštatovat', že Jozef Bartakovič pri jeho kreovaní postupoval v zhode s teoretickými východiskami čistopisu Commentarii in Litteras Humaniores, resp. jeho state De Drammatibus, ked’že v danej súvislosti nezohladnil iba dobovú konvenciu jeho vnútorného usporiadania na štyri koherentné časti, ale využil aj oba druhy fikcie (v súlade a v protiklade s históriou). Tým sa mu do dramatického deja podarilo pridat zápletku, ktorá nie je ani príliš jednoduchá, ani príliš komplikovaná, a ktorá je vybudovaná na nevyhnutnom princípe pravdepodobnosti. ${ }^{47}$

Spomedzi šiestich (z celkového počtu desiatich) podkapitol dramatickej poetiky analyzovaného rukopisu skalického kompendia zaoberajúcich sa vlastnou teóriou drámy sme sa doposial' nezmienili o miere kontextuálneho presahu podkapitoly De

${ }^{44}$ Zárodky vzbury sa Mojžišovi spočiatku podarí potlačit', avšak len čo spolu s Áronom odíde za faraónom, aby uňho dosiahol prepustenie Elysama, všetci traja buriči ju v izraelskom tábore rozpútajú nanovo, pričom zo strachu pred faraónovým trestom pre útek Izraelitov z Egypta navyše zosnujú plán na fyzickú likvidáciu Mojžiša po jeho návrate do tábora.

${ }^{45}$ Korachovo, Datánovo a Abirónovo zistenie, že muži, ktorých zavraždili, nie sú Mojžiš s Áronom, ale faraónovi mágovia Jannes a Mambres.

${ }^{46}$ Mojžišovo (presnejšie Božie) milosrdenstvo.

${ }^{47}$ Porov. Moyses. Tyrnaviae : Typis Academicis, 1749. OSZK 319.146 a Commentarii in Litteras Humaniores, s. $92-94$. 
Constructione Periochae (O zostavení periochy) v sujete tragédie Moyses. Dôvodom je skutočnost', že spomínaná podkapitola, ako to vyplýva už z jej názvu, pojednáva najmä o formálnych aspektoch štruktúry jezuitských barokových perioch. Aj napriek tomuto faktu sa ako nesmierne zaujímavá javí komparácia jej odporúčaní s formou kompozície tlačenej periochy školskej hry Jozefa Bartakoviča, ktorý aj v tomto prípade rešpektoval príslušné teoretické usmernenia. Pre potreby uvedenia svojej výpravnej tragédie, či skôr pre potreby trnavského obecenstva, zostavil synopsu v troch jazykových mutáciách - latinskej, mad’arskej a nemeckej. V jej argumente uviedol jednak zmienku o prítomnosti básnickej licencie (v súvislosti s fiktívnou postavou Elysama), a to poznámkou o úprave námetu školskej drámy v protiklade s históriou, a jednak informáciu o mieste dramatického deja. Navyše, zoznam dramatických postáv umiestnil (na rozdiel od záverečného zoznamu účinkujúcich študentov) v záujme prehl'adnosti hned' pod argumentum, ktoré sa nachádza spravidla v úvode každej periochy. $^{48}$

\section{Záver}

Komparácia signifikantných historických prameňov slovenského divadelného baroka, t. j. čistopisu skalického rukopisného kompendia latinského jazyka a reálií s názvom Commentarii in Litteras Humaniores, ktorý pochádza pravdepodobne z prvej polovice 18. storočia, a tlačeného textu (spolu s tlačenou periochou) tragédie Jozefa Bartakoviča s názvom Moyses z roku 1749 preukázala, že miera uplatňovania teoretických východísk dramatických poetík najvýznamnejších európskych jezuitských autorov v rádovej dramaticko-divadelnej praxi na území dnešného Slovenska bola v období baroka maximálna. Presviedča nás o tom autorsko-režijný prístup Jozefa Bartakoviča ku komponovaniu a následnému inscenovaniu tragédie vo vel'kej divadelnej sále trnavského univerzitného divadla. Autor v danej súvislosti uprednostnil vel’mi známy náboženský námet pred svetským a zároveň starý námet zahraničnej proveniencie pred súčasnou domácou tematikou. Námet popritom prispôsobil veku hercov, dramatický dej vnútorne diferencoval na štyri koherentné časti (prothasis, epithasis, catastasis, catastrophe) a pri vytváraní dramatickej zápletky využil oba druhy fikcie (v súlade a v protiklade s históriou), čím sa mu v sujete školskej drámy popri vyzdvihnutí cnosti podarilo docielit’ predovšetkým prirodzenost’ a pravdepodobnost’ dramatického deja, fikcie a zápletky. Tieto rezultáty možno označit za (v slovenskej historiografii doposial' absentujúcu) verifikáciu tézy Stanislava Weissa-Nägela, ktorú publikoval vo svojej doteraz neprekonanej syntetickej práci s názvom Jezuitské divadlo na Slovensku v XVII. a XVIII. storočí (1935) a ktorou upozornil na skutočnost', že naša jezuitská dramaticko-divadelná produkcia rešpektovala v druhej polovici 17. a v 18. storočí tendencie vývoja európskej školskej hry, čím zapájala naše rádové divadelníctvo do celoeurópskeho prúdu barokovej literárno-umeleckej tradície. $^{49}$

${ }^{48}$ Porov. Moyses. Tyrnaviae : Typis Academicis, 1749. ELTE EKL, KNY_18_00967 a Commentarii in Litteras Humaniores, s. $100-102$.

${ }^{49}$ Pozri WEISS-NÄGEL, S. Jezuitské divadlo na Slovensku v XVII. a XVIII. storočí. In Pamiatke trnavskej univerzity 1635 - 1777. Trnava : Spolok sv. Vojtecha, 1935, s. 266 - 306. 


\section{JESUIT DRAMA THEORY AND ITS REFLECTION ON THE BAROQUE SCHOOL THEATRE OF THE SOCIETY OF JESUS IN THE TERRITORY OF PRESENT-DAY SLOVAKIA}

\section{Lukáš KOPAS}

The aim of the study is to describe how the theoretical foundations of the most prominent Jesuit drama poetics were applied in the Jesuit order drama and theatre practice in the territory of present-day Slovakia during the Baroque period. The subject of the study is a discourse between the theoretical frameworks of one of the four known essential teaching aids of the Jesuit grammar school in Skalica, Collegium repetentium humaniorum - a manuscript of the compendium of the Latin language and realia entitled Commentarii in Litteras Humaniores, (Notes on Human Sciences) whose chapter De Drammatibus (On Drama) summarises the Jesuit theory of drama of prominent 17th century European authors - and the plotline of a Jesuit school play by Jozef Bartakovič Moyses (Moses), which was staged in July 1749 in Trnava.

Realizáciu výskumu podporil z verejných zdrojov formou štipendia Fond na podporu umenia

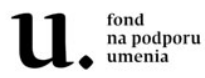

\section{LITERATÚRA A PRAMENE}

ALSZEGHY, Zsoltné - BERECZ, Ágnes - KERESZTES, Attila - KISS, Katalin - KNAPP, Éva - VARGA, Imre. Jezsuita iskoladrámák: (ismeretlen szerzók) programok, színlapok. Budapest : Akadémiai Kiadó - Argumentum Kiadó, 1995. 1105 s. ISBN 963-4460-01-1.

ARISTOTELES. Poetika. Martin : THETIS, 2009. 145 s. ISBN 978-80-970115-3-6.

BOBKOVÁ-VALENTOVÁ, Kateřina. Každodenní život učitele a žáka jezuitského gymnázia. Praha : Karolinum, 2006. 280 s. ISBN 80-246-1082-5.

Commentarii in Litteras Humaniores. OSZK, Quart. Lat. 3271.

DONATUS, Alessandro. Ars poetica. Venetiis : Sumptibus Combi, \& Lanovii, 1684. 536 s.

DROBĚNOVÁ, Zuzana. Študenti a profesori. In Dejiny Trnavskej univerzity 1635 - 1777, 1992 - 2010. (Ed. Jozef Šimončič, Alžbeta Hološová). Trnava : Typi Universitatis Tyrnaviensis, 2010, s. 157 - 179. ISBN 978-80-8082-353-5.

JACKOVÁ, Magdaléna. Divadlo jako škola ctnosti a zbožnosti : jezuitské školské drama v Praze v proní polovině 18. století. Praha : Filozofická fakulta Univerzity Karlovy, 2011. 278 s. ISBN 97880-7308-360-1.

KAČIC, Ladislav. Jezuitská školská hra a hudba na Slovensku v 17. - 18. storočí. In Jezuitské školstvo včera a dnes : zborník z medzinárodnej vedeckej konferencie 12. októbra 2006 v Trnave. (Ed. Ladislav Csontos). Trnava : Dobrá kniha, 2006, s. 175 - 188. ISBN 80-7141-545-6.

KAČIC, Ladislav. Jezuitská školská hra, hudba a tanec. In Slovenské divadlo, 1998, roč. 46, č. 1 , s. 33 - 42. ISSN 0037-699X.

Komentáre k Starému zákonu 3 : Exodus. (Ed. Jozef Tiňo). Trnava : Dobrá kniha, 2013. 948 s. ISBN 978-80-7141-766-8.

MARSINA, Richard. Filozofická fakulta 1635 - 1777. In Dejiny Trnavskej univerzity 1635 - 1777, 1992 - 2010. (Ed. Jozef Šimončič, Alžbeta Hološová). Trnava : Typi Universitatis Tyrnaviensis, 2010, s. 63 - 77. ISBN 978-80-8082-353-5. 
MARSINA, Richard. Samuel Timon a Trnavská univerzita. In Trnavská univerzita 1635 - 1777 : 1. Referáty zo seminára $k$ 360. výročiu založenia. 2. Príspevky z cirkevných dejín Slovenska. (Ed. Jozef Šimončič). Trnava : Trnavská univerzita, 1997, s. 209 - 241. ISBN 80-88774-15-2.

MINÁRIK, Jozef. Baroková literatúra svetová, česká, slovenská. Bratislava : Slovenské pedagogické nakladatel'stvo, 1984. $388 \mathrm{~s}$.

Moyses. Tyrnaviae : Typis Academicis, 1749. 23 s. ELTE EKL, KNY_18_00967.

Moyses. Tyrnaviae : Typis Academicis, 1749. 64 s. OSZK 319.146.

PAŠTEKA, Július. K trnavskej tradícii jezuitského barokového divadla : niekolko poznámok na okraj vel'kej témy. In Slovenské divadlo, 1993, roč. 41, č. 3, s. 227 - 259. ISSN 0037-699X.

PINTÉR, Márta Zsuzsanna. A ferences iskolai színjátszás a 18. században. Budapest : Argumentum Kiadó, 1993. 161 s. ISBN 963-771-940-7.

PINTÉR, Márta Zsuzsanna. Theatrum és literatúra. Budapest : Universitas Könyvkiadó, 2014. 278 s. ISBN 978-963-9671-46-1.

POLEHLA, Petr. Jezuitské divadlo ve službě zbožnosti a vzdělanosti. Červený Kostelec : Pavel Mervart, 2011. 163 s. ISBN 978-80-87378-81-6.

PORIEZOVÁ, Miriam. Ad usum juventutis : jazyková literatúra vo vydavatel'skom programe trnavskej Akademickej tlačiarne (1648-1773). In Studia bibliographica Posoniensia I/2006. (Ed. Miriam Poriezová). Bratislava : Univerzitná knižnica, 2006, s. 130 - 138. ISBN 80-85170-97-3.

SOPKO, Július. Dobová latinská jazyková kultúra na školách a Trnavská univerzita. In Trnavská univerzita $v$ dejinách školstva a vzdelanosti : zborník referátov vedeckej konferencie konanej v Bratislave dňa 26. novembra 1985 pri príležitosti 350. výročia založenia Trnavskej univerzity. (Ed. Mária Novacká). Bratislava : Slovenská pedagogická knižnica, 1986, s. 86 -104.

STAUD, Géza. A magyarországi jezsuita iskolai színjátékok forrásai I. 1561-1773. Budapest : A Magyar Tudományos Akadémia, 1984. 504 s. ISBN 963-7301-63-1.

WEISS-NÄGEL, Stanislav. Jezuitské divadlo na Slovensku v XVII. a XVIII. storočí. In Pamiatke trnavskej univerzity 1635 - 1777. Trnava : Spolok sv. Vojtecha, 1935, s. 259 - 307.

Lukáš Kopas

Centrum výskumu divadla Divadelného ústavu

Jakubovo námestie 12

81357 Bratislava

e-mail: lukas.kopas@theatre.sk 